DOE/ID/12584-261

GJPO-GJ-31

U.S. Department of Energy

Grand Junction Projects Office Remedial Action Project

Final Report of the Decontamination and Decommissioning of Building 52 at the Grand Junction Projects Office Facility

August 1996

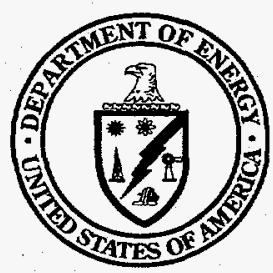

U.S. Department of Energy Grand Junction Projects Office

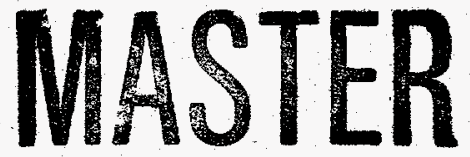

Approved for public release; distribution is unlimited.

Work Performed Under DOE Contract No. DE-AC04-86ID12584 for the U.S. Department of Energy 
This report was prepared as an account of work sponsored by an agency of the United States Government. Neither the United States Government nor any agency thereof, nor any of their employees, makes any warranty, express or implied, or assumes any legal liability or responsibility for the accuracy, completeness, or usefulness of any information, apparatus, product, or process disclosed in this report, or represents that its use would not infringe privately owned rights. Reference herein to any specific commercial product, process, or service by trade name, trademark, manufacturer, or othenwise, does not necessarily constitute or imply its endorsement, recommendation, or favoring by the United States Government or any agency thereof. The views and opinions of authors expressed herein do not necessarily state or reflect those of the United States Government or any agency thereof. 


\title{
Final Report \\ of the Decontamination and Decommissioning of Building 52 at the Grand Junction Projects Office Facility
}

August 1996

\author{
Prepared for \\ U.S. Department of Energy \\ Albuquerque Operations Office \\ Grand Junction Projects Office \\ Grand Junction, Colorado
}

\section{Prepared by}

Rust Geotech

Grand Junction, Colorado

Technical Coordination and Reports Project Number TCR-031-0005-00-000
Technical Coordination and Reports Document Number T0001500

Rust Geotech has been granted authorization to conduct remedial action under the Decontamination and Decommissioning Program. Remedial action was conducted in accordance with all applicable or relevant and appropriate requirements.

Work Performed Under DOE Contract No. DE-AC04-86ID12584

Approved for public release; distribution is unlimited. 
This page intentionally blank 


\section{Signature Page}

\section{Prepared by:}
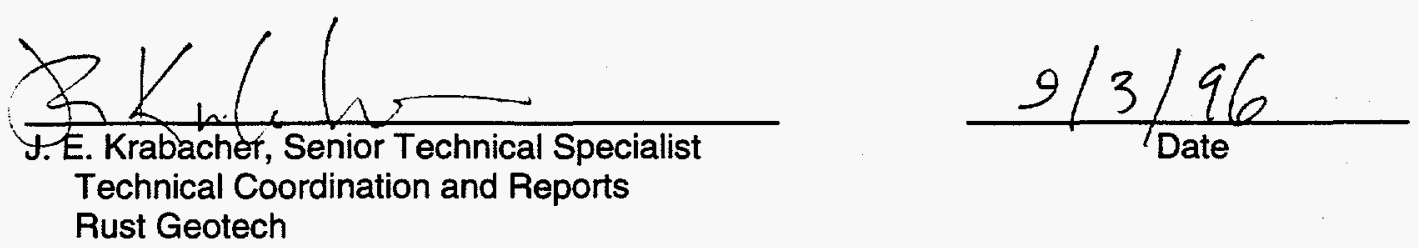

\section{Approved by:}

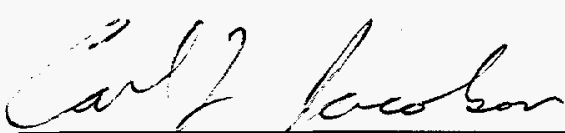

C. L. Jacobson, Program Manager Decommissioning Programs Rust Geotech

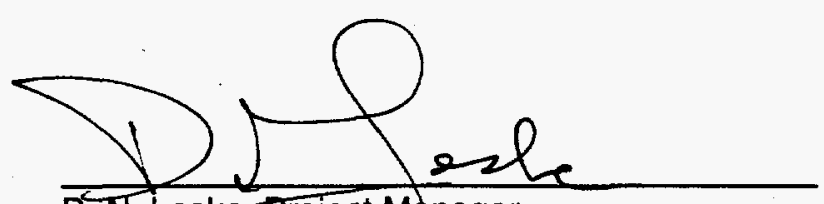

D.N. Leske, Project Manager

U.S. Department of Energy Grand Junation Projects Office
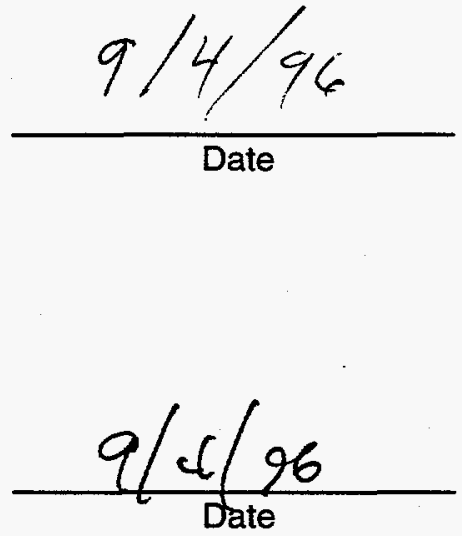
This page intentionally blank 


\section{DISCLAIMER}

Portions of this document may be illegible in electronic image products. Images are produced from the best available original document. 


\section{DISCLAIMER}

This report was prepared as an account of work sponsored by an agency of the United States Government. Neither the United States Government nor any agency thereof, nor any of their employees, makes any warranty, express or implied, or assumes any legal liability or responsibility for the accuracy, completeness, or usefulness of any information, apparatus, product, or process disclosed, or represents that its use would not infringe privately owned rights. Reference herein to any specific commercial product, process, or service by trade name, trademark, manufacturer, or otherwise does not necessarily constitute or imply its endorsement, recommendation, or favoring by the United States Government or any agency thereof. The views and opinions of authors expressed herein do not necessarily state or reflect those of the United States Government or any agency thereof. 


\section{Abstract}

The U.S. Department of Energy (DOE) Grand Junction Projects Office (GJPO) occupies a 61.7-acre facility along the Gunnison River near Grand Junction, Colorado. This site was contaminated with uranium ore and mill tailings during uranium refining activities of the Manhattan Engineer District and during pilot milling experiments conducted for the U.S. Atomic Energy Commission's domestic uranium procurement program. The DOE Defense Decontamination and Decommissioning Program established the GJPO Remedial Action Project to clean up and restore the facility lands, improvements, and the underlying aquifer. The site contractor for the facility, Rust Geotech, also was the remedial action contractor.

Building 52 was found to be radiologically contaminated and was demolished in 1994 . The soil area within the footprint of the building has been remediated in accordance with the identified standards and the area can be released for unlimited exposure and unrestricted use. This document was prepared in response to a DOE request for an individual final report for each contaminated GJPO building. 
This page intentionally blank 


\section{Contents}

Page

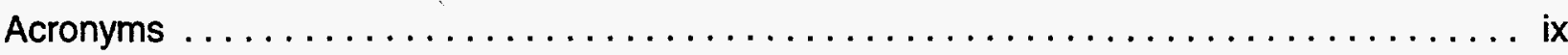

I. Introduction and Background $\ldots \ldots \ldots \ldots \ldots \ldots \ldots \ldots \ldots \ldots \ldots \ldots \ldots \ldots \ldots$

Description of Facility $\ldots \ldots \ldots \ldots \ldots \ldots \ldots \ldots \ldots \ldots \ldots \ldots \ldots \ldots$

Description of Project $\ldots \ldots \ldots \ldots \ldots \ldots \ldots \ldots \ldots \ldots \ldots \ldots \ldots \ldots \ldots \ldots \ldots$

Description of Building $52 \ldots \ldots \ldots \ldots \ldots \ldots \ldots \ldots \ldots \ldots \ldots \ldots \ldots \ldots$

Basis for Remedial Action $\ldots \ldots \ldots \ldots \ldots \ldots \ldots \ldots \ldots \ldots \ldots \ldots \ldots \ldots$

11. Decommissioning Criteria, Objectives, and Work Scope $\ldots \ldots \ldots \ldots \ldots \ldots \ldots \ldots$

Applicable Guidelines and Standards . . . . . . . . . . . . . . . . . 3

III. Work Performed . . . . . . . . . . . . . . . . . . . . . . . . . . . . 3

Remedial Investigation/Feasibility Study and Record of Decision $\ldots \ldots \ldots \ldots \ldots$

Characterization $\ldots \ldots \ldots \ldots \ldots \ldots \ldots \ldots \ldots \ldots \ldots \ldots \ldots \ldots \ldots \ldots$

Remedial Design ................................. 4

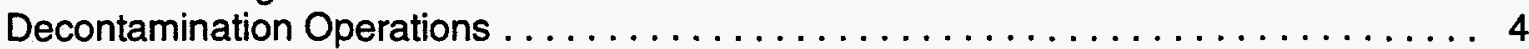

IV. Final Release Survey $\ldots \ldots \ldots \ldots \ldots \ldots \ldots \ldots \ldots \ldots \ldots \ldots \ldots \ldots \ldots$

Instrumentation $\ldots \ldots \ldots \ldots \ldots \ldots \ldots \ldots \ldots \ldots \ldots \ldots \ldots \ldots \ldots \ldots$

Background Determinations $\ldots \ldots \ldots \ldots \ldots \ldots \ldots \ldots \ldots \ldots \ldots \ldots \ldots$

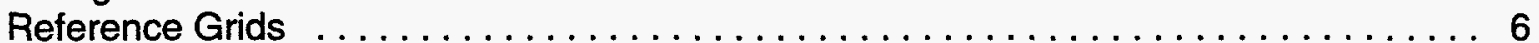

Scanning Results . . . . . . . . . . . . . . . . . . . . . . . . 6

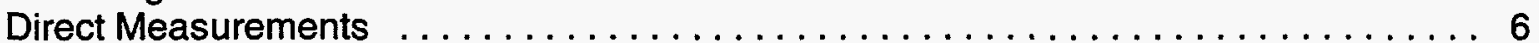

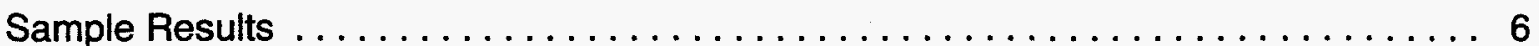

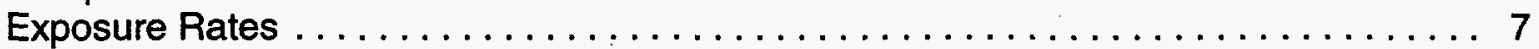

V. Cost and Schedule $\ldots \ldots \ldots \ldots \ldots \ldots \ldots \ldots \ldots \ldots \ldots \ldots \ldots \ldots \ldots \ldots$

VI. Occupational Exposure $\ldots \ldots \ldots \ldots \ldots \ldots \ldots \ldots \ldots \ldots \ldots \ldots \ldots \ldots \ldots$

VIl. Waste Volumes $\ldots \ldots \ldots \ldots \ldots \ldots \ldots \ldots \ldots \ldots \ldots \ldots \ldots \ldots \ldots \ldots$

VIII. Final Condition $\ldots \ldots \ldots \ldots \ldots \ldots \ldots \ldots \ldots \ldots \ldots \ldots \ldots \ldots \ldots \ldots \ldots$

IX. Lessons Learned $\ldots \ldots \ldots \ldots \ldots \ldots \ldots \ldots \ldots \ldots \ldots \ldots \ldots \ldots \ldots \ldots \ldots \ldots$

X. References $\ldots \ldots \ldots \ldots \ldots \ldots \ldots \ldots \ldots \ldots \ldots \ldots \ldots \ldots \ldots \ldots$

\section{Figures}

Figure 1. Site Map of the DOE-GJPO Facility, Grand Junction, Colorado $\ldots \ldots \ldots \ldots$

2. Extent of Contamination and Verification Areas $\ldots \ldots \ldots \ldots \ldots \ldots \ldots \ldots$ 


\section{Tables}

Table 1. Applicable or Relevant and Appropriate Standards . . . . . . . . . . . 4

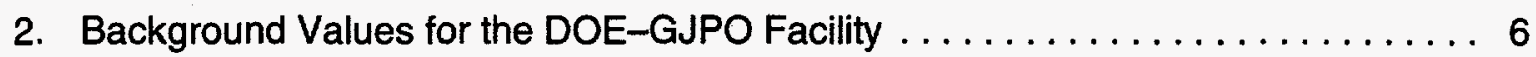

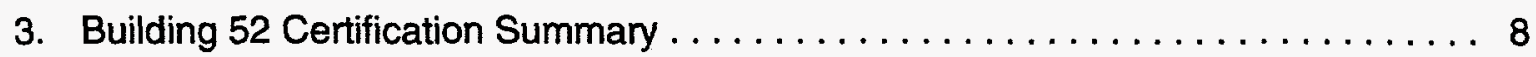

B-1. Post-Remediation Sample/Measurement Results for an Exterior Area ...... B-3

\section{Appendices}

Appendix A. Applicable Program and Quality Assurance

Requirements and Procedures

A-1

Appendix B. Final Radiological Conditions . . . . . . . . . . . . . . . . B-1 


\section{Acronyms}

CERCLA Comprehensive Environmental Response, Compensation, and Liability Act

CFR U.S. Code of Federal Regulations

D\&D decontamination and decommissioning

DOE U.S. Department of Energy

FUSRAP Formerly Utilized Sites Remedial Action Program

GJPO Grand Junction Projects Office

GJPORAP Grand Junction Projects Office Remedial Action Project

IVC independent verification contractor

LTSM long-term surveillance and maintenance

QA quality assurance

Ra-226 Radium-226

RAC remedial action contractor

ROD Record of Decision

SARA Superfund Amendments and Reauthorization Act

SFMP Surplus Facilities Management Program

U.S.C. United States Code 
This page intentionally blank 


\section{Introduction and Background}

This report summarizes the results of the remedial action conducted on Building 52 at the U.S. Department of Energy Grand Junction Projects Office (DOE-GJPO) facility. This building was radiologically contaminated. Demolition was identified as the most costeffective remedial action alternative and the building was demolished in 1994. The soil within the building footprint complies with applicable regulations and can be released for unrestricted use and unlimited exposure. After all Grand Junction Projects Office Remedial Action Project (GJPORAP) remedial action is completed, the facility is expected to be transferred to the Long-Term Surveillance and Maintenance (LTSM) Program to allow restoration of the aquifer. The remediation of the exterior land areas and the other buildings and associated utilities on the DOE-GJPO facility will be summarized in separate reports.

\section{Description of Facility}

The DOE-GJPO facility is located approximately 0.6 mile (1 kilometer) south and west of populated areas of the city of Grand Junction in Sections 26 and 27, Township 1 South, Range 1 West, Ute Principal Meridian, Mesa County, Colorado (Figure 1). The facility occupies 61.7 acres $^{*}$ ( 25 hectares) of floodplain within an accretionary bend along the east bank of the Gunnison River.

The elevation of the DOE-GJPO facility is approximately 4,560 feet (1,390 meters). The facility is situated on silty sandy gravel underlain by mudstone bedrock. Two bodies of water, the North Pond and the South Pond, with associated wetlands, are located on the DOE-GJPO facility. A freshwater alluvial aquifer underlying the facility is in direct hydraulic contact with the ponds and the Gunnison River. A semi-arid climate prevails.

Access to the occupied portion of the facility is restricted by security personnel and a fence.

\footnotetext{
"Previous to the reacquisition of Black Bridge Park, the facility occupied approximately 56.4 acres.
}

There are approximately 40 structures on the facility. Outside the security fence are vehicle parking lots to the east and an earthen dike along the Gunnison River to the west and north. The area adjacent to the facility to the north was formerly Black Bridge Park, now owned by DOE. The facility is bordered on the east by the Southern Pacific Railroad (formerly the Denver and Rio Grande Western Railroad) right-of-way.

DOE-GJPO facility lands were acquired by the U.S. War Department in 1943 for the Manhattan Engineer District. A refinery was operated on the site from 1943 to 1946 to treat and concentrate uranium oxide. The U.S.

Atomic Energy Commission operated a uraniumconcentrate sampling plant and assay laboratory on the site until 1974. Pilot-scale uranium ore mills were operated from 1953 to 1958 , processing 30,000 tons $(27,200$ metric tons) of ore (DOE 1987a). Mill operations were the primary source of contaminated materials at the DOE-GJPO facility, resulting in the on-site burial of approximately 247,000 cubic yards $\left(\mathrm{yd}^{3}\right)$, or 189,000 cubic meters $\left(\mathrm{m}^{3}\right)$ of uranium ore tailings. Other potential sources of contamination included laboratory and vehicle-maintenance wastes and byproducts, and activities related to sampling and stockpiling uranium concentrates. Approximately 22 acres ( 8.9 hectares) of open land and 19 buildings were contaminated.

\section{Description of Project}

In 1984, the DOE-GJPO facility was accepted into the DOE Surplus Facilities Management Program (SFMP) for the purpose of eliminating health hazards resulting from uranium mill tailings and associated contaminated materials at the facility, and to bring contaminated portions of the facility, including the underlying aquifer, into compliance with applicable environmental regulations. In 1988 , the facility was transferred to the DOE Decontamination and Decommissioning (D\&D) Program. The D\&D Program is responsible for the surveillance and maintenance of surplus DOE facilities, including any necessary decontamination and decommissioning activities. 


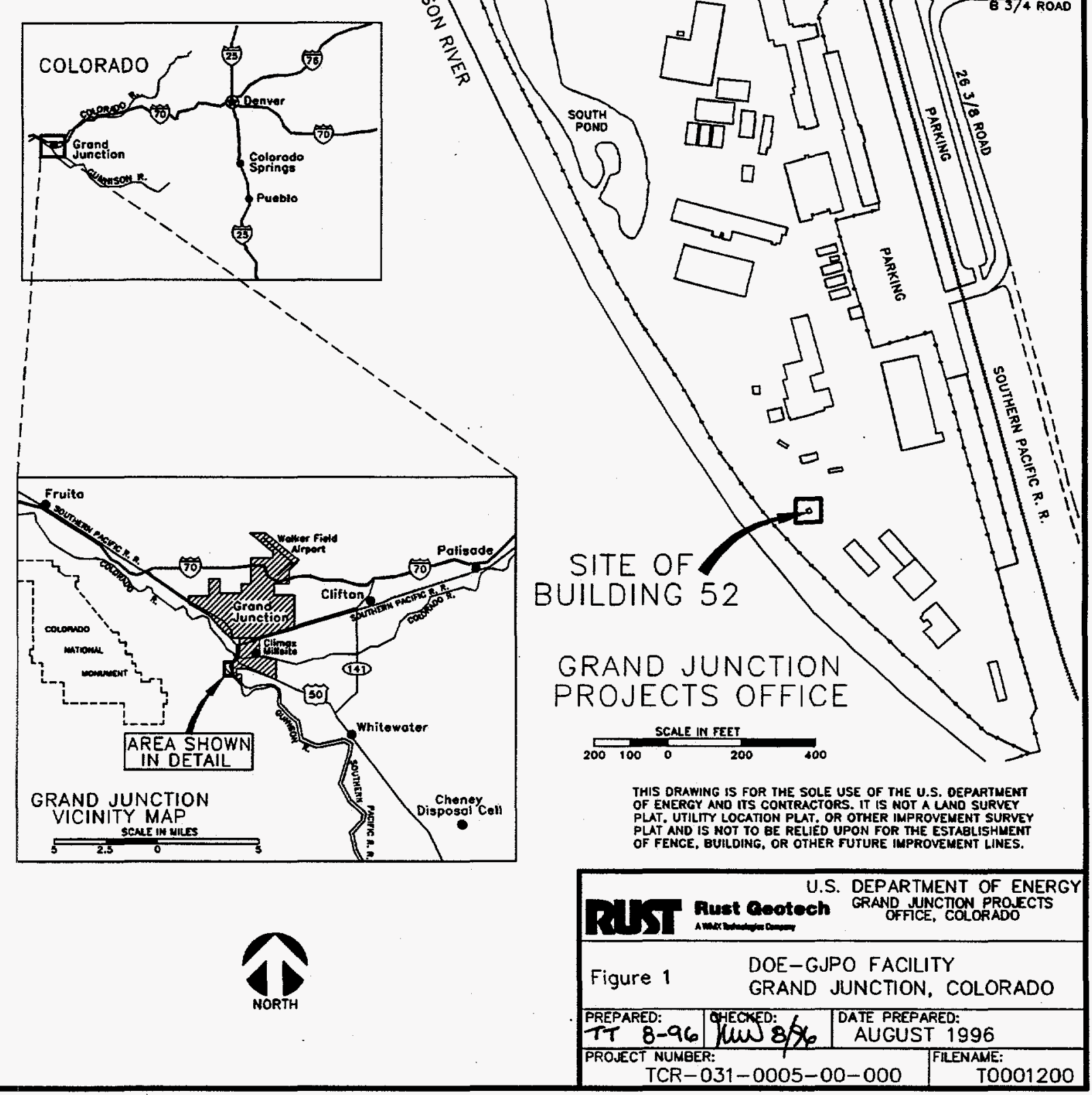

Figure 1. Site Map of the DOE-GJPO Facility, Grand Junction, Colorado 
DOE-GJPO has specific responsibility for GJPORAP under the D\&D Program. Rust Geotech was the remedial action contractor (RAC) for GJPORAP. The GJPORAP organization and implementation strategy was defined in the Grand Junction Projects Office Remedial Action Project Remedial Action Plan (DOE 1990c).

\section{Description of Building 52}

Building 52 was a wood-frame structure covered with corrugated sheet-metal siding and roofing, with a wood floor and foundation. The building had a footprint of 126 square feet $\left(\mathrm{ft}^{2}\right)$ (11.7 meters square $\left[\mathrm{m}^{2}\right]$ ). It was constructed in 1956 to store oil and grease for the pilot plant uranium-milling activities (Rust 1996). After the cessation of milling activities it was used for storage. Before 1990, it was used to store a small quantity of uranium mill tailings and a radium-226 (Ra-226) source. These sources were used to generate radon for radon flux measurements and experiments. The tailings were placed in an open soil-lined sump dug into the ground beneath the floor.

\section{Basis for Remedial Action}

In 1980, the U.S. Congress enacted the Comprehensive Environmental Response, Compensation, and Liability Act (CERCLA) (42 United States Code [U.S.C.] 9601). In 1986, Congress amended CERCLA with the Superfund Amendments and Reauthorization Act (SARA).

Section 120 of SARA and Executive Order 12580, Superfund Implementation, directed DOE to coordinate with the U.S. Environmental Protection Agency to respond to actual or potentially imminent releases of hazardous substances into the environment at federally owned DOE facilities. D\&D Program policy specifies that remedial action will be conducted in accordance with DOE Order 5480.1B, Environment, Safety, and Health Program for Department of Energy Operations, and all other applicable environmental regulations.

The DOE-GJPO facility was evaluated using the CERCLA Hazard Ranking System.

Although the resulting score of 14.6 (DOE
$1989 \mathrm{~b})$ did not qualify the facility for placement on the National Priorities List, remedial action under GJPORAP conformed to the applicable provisions of CERCLA, as amended by SARA, and the Uranium Mill Tailings Radiation Control Act (42 U.S.C. 7901), the National

Environmental Policy Act (42 U.S.C. 4321), and other applicable Federal and State regulations. Remedial action was conducted with an emphasis on maintaining all health and safety risks as low as reasonably achievable.

\section{Decommissioning Criteria, Objectives, and Work Scope}

\section{Applicable Guidelines and Standards}

Table 1 presents the guidelines that specify the authorized limits for GJPORAP.

Remedial action activities were conducted in accordance with the Rust Quality Assurance [QA] Manual (Manual 101) and approved plans and procedures (Appendix A), which incorporate the applicable provisions of the Quality Assurance Program for Nuclear Facilities, NQA-1 (ASME 1989).

\section{Work Performed}

\section{Remedial Investigation/Feasibility Study and Record of Decision}

The Remedial Investigation/Feasibility Study -Enyironmental Assessment for GJPORAP was released in 1989 (DOE 1989a). Building 52 was not included in this study because it was outside the original scope of GJPORAP. Consequently, remediation of this building was not addressed in the Record of Decision (ROD) (DOE 1990a).

Post-ROD Changes-An Explanation of Significant Differences will be prepared at the conclusion of GJPORAP remedial action activities to address departures from the ROD, including the demolition of Building 52 . 
Table 1. Applicable or Relevant and Appropriate Standards

\begin{tabular}{|l|l|}
\hline \multicolumn{1}{|c|}{ Type of Occurrence } & \multicolumn{1}{c|}{ Standard } \\
\hline Contamination in Soil & $\begin{array}{l}40{\text { CFR } 192^{\mathrm{a}}}^{\text {FUSRAP/SFMP Guidelines }}{ }^{\mathrm{b}} \\
\text { DOE Order } 5400.5^{\mathrm{c}}\end{array}$ \\
\hline Surface Activity (structural surfaces) & $\begin{array}{l}\text { FUSRAP/SFMP Guidelines } \\
\text { DOE Order } 5400.5^{\mathrm{c}}\end{array}$ \\
\hline Gamma Exposure Rate (interior areas) & $\begin{array}{l}40 \text { CFR } 192^{\mathrm{a}} \\
\text { FUSRAP/SFMP Guidelines } \\
\text { DOE Order } 5400.5^{\circ}\end{array}$ \\
\hline Radon Decay-Product Concentration (interior areas) & $\begin{array}{l}40 \text { CFR } 192^{\mathrm{a}} \\
\text { FUSRAP/SFMP Guidelines } \\
\text { DOE Order } 5400.5^{\circ}\end{array}$ \\
\hline
\end{tabular}

${ }^{2}$ Title 40, U.S. Code of Federal Regulations Part 192 (40 CFR 192), "Health and Environmental Protection Standards for Uranium and Thorium Mill Tailings."

${ }^{b}$ Guidelines for Residual Radioactive Material at Formerly Utilized Sites Remedial Action Program [FUSRAP] and Remote Surplus Facilities Management Program Sites, (DOE 1987b).

${ }^{\mathrm{C} D O E}$ Order 5400.5, Radiation Protection of the Public and the Environment.

\section{Characterization}

Building 52 was routinely surveyed for radiological hazards (Rust 1993, Rust 1994a). The surveys included measurements of gamma exposure rates; and alpha and beta-gamma scans, direct measurements, and smears.

Radiological Contamination-The original characterization survey did not detect any removable alpha or beta activity in excess of the release guidelines. However, fixed (nonremovable) contamination was detected, with activities ranged as high as 194,300 disintegrations per minute per 100 square centimeters $\left(\mathrm{dpm} / 100 \mathrm{~cm}^{2}\right)$. Gamma exposure rates exceeded 2,000 microroentgens per hour $(\mu \mathrm{R} / \mathrm{h})$, mostly due to the uranium mill tailings and $\mathrm{Ra}-226$ source stored inside. The characterization surveys identified contamination in the interior walls, the floor, and the underlying soil.

Nonradiological Contamination-No hazardous nonradiological contamination was identified in or near Building 52.

\section{Remedial Design}

Remediation of Building 52 became part of the scope of GJPORAP after the ROD was approved. The selected remediation alternative was demolition. The objective of the remediation plan was to eliminate real and potential health hazards to workers, the public, and the environment. The remediation process involved demolishing the building, removing the floor, and remediating the underlying soil; following approved procedures using standard construction techniques. Radiologically contaminated materials were impounded at the Cheney Disposal Cell. After removal of uranium mill tailings and other associated contaminated material, the affected area was reconstructed. A plan for proper management of any nonradiological hazardous materials was in effect.

\section{Decontamination Operations}

Summary of Remedial Action-Building 52 was demolished in September 1994 (Rust 1994b). Excavation of soil beneath the building continued until gamma measurements indicated that all soil with elevated gamma activity was removed. Analyses of the underlying soil indicated that the remaining soil was not contaminated. The depth of the excavation ranged from 12 to 36 inches.

Radiological Contamination-The exterior areas adjacent to Building 52 were remediated in 


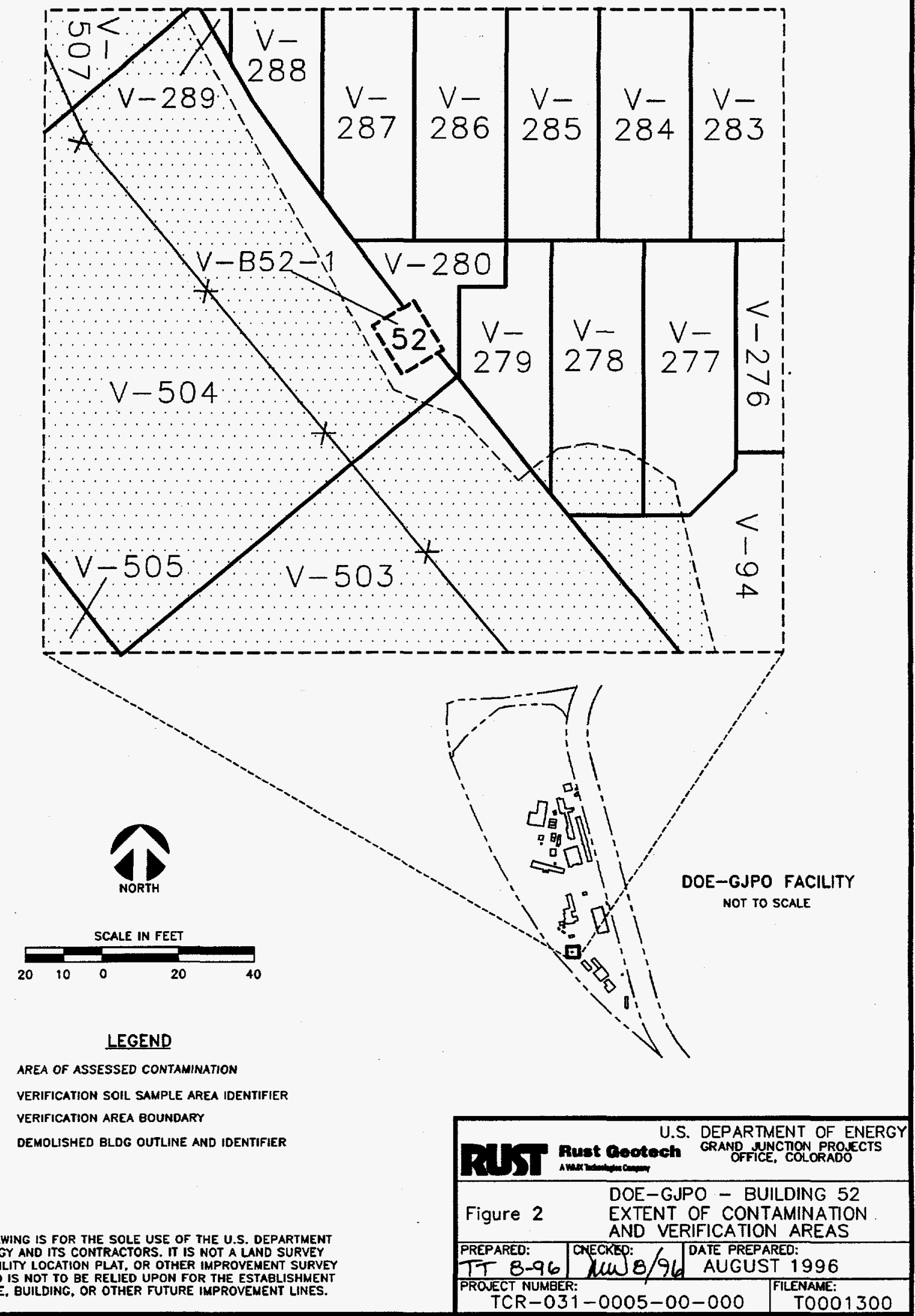

Figure 2. Extent of Contamination and Verification Areas 
1989 during construction Phases IA and II/III (Figure 2). In 1994, radiological contamination, including building debris, was removed from within the area of Building 52, as indicated by the results of soil sample analyses and gamma exposure rate scans (Appendix Table B-1). All material from this remedial action was disposed at the Cheney Disposal Cell.

\section{Final Release Survey}

The final status surveys of the soil underlying the location of Building 52 were conducted in accordance with the Rust Health and Safety Manual (Manual 103), Volume 1, the Rust Field Assessments Procedures Manual, and approved plans (DOE 1990c). This work was conducted prior to the adoption of the Survey Plan for Releasing the Buildings at the Grand Junction Projects Office (DOE 1995).

Oak Ridge National Laboratory at Grand Junction was the independent verification contractor (IVC) for GJPORAP. Oversight activities were conducted by RAC QA personnel and representatives of the Colorado Department of Public Health and Environment.

\section{Instrumentation}

Radiation detection instruments were calibrated and used in accordance with the Rust Field Assessments Procedures Manual. Calibrations used traceable standards and complied with 10.CFR 835, "Occupational Radiation Protection," DOE Order 5480.11, Radiation Protection for Occupational Workers, and DOE Order 5480.4, Environmental Protection, Safety, and Health Protection Standards.

\section{Background Determinations}

Background values determined for the DOE-GJPO facility are summarized in Table 2.

\section{Reference Grids}

Grids were not established in the area of Building 52. For Building 52, one verification area was established (Figure 2).

\section{Scanning Results}

No structural surfaces remain in this area; therefore, direct scanning for alpha or betagamma surface activity was not conducted.

\section{Direct Measurements}

No structural surfaces remain in this area; therefore, direct measurements for alpha or betagamma surface activity were not taken.

\section{Sample Results}

A soil sample comprised of 6 aliquots representing the 6 inches $(15 \mathrm{~cm})$ of soil from the floor of the excavation beneath the building was collected. The area represented by this sample extended to the footprint of Building 52 (Figure 2). This sample was analyzed for Ra-226 (Appendix Table B-1). As a cost-saving measure, analysis for total uranium was not conducted because the sample exhibited less than $2,500 \mathrm{dpm} / 100 \mathrm{~cm}^{2}$ beta-gamma activity when scanned at the time of collection. This betagamma value correlates to a measurable uranium concentration within the authorized limit, as shown by extensive sampling conducted in other areas; and sample analyses results indicated that

Table 2. Background Values for the DOE-GJPO Facility

\begin{tabular}{|l|c|c|}
\hline \multicolumn{1}{|c|}{ Criterion } & Background Value & Source of Data \\
\hline Gamma Exposure Rate-Exterior & $14 \mu \mathrm{R} / \mathrm{h}$ & DOE 1986 \\
\hline Ra-226 Concentration in Soil & $1.0 \mathrm{pCi} / \mathrm{g}$ & DOE 1990b \\
\hline Thorium-230 Concentration in Soil & $2.0 \mathrm{pCi} / \mathrm{g}$ & DOE 1990b \\
\hline Total Uranium Concentration in Soil & $2.0 \mathrm{pCi} / \mathrm{g}$ & DOE 1990b \\
\hline
\end{tabular}

Key: $\mu \mathrm{R} / \mathrm{h}=$ microroentgens per hour; $\mathrm{pCi} / \mathrm{g}=$ picocuries per gram 
uranium probably was not a contaminant of concern.

\section{Exposure Rates}

One hundred percent of the exposed soil surface was scanned for gamma activity. Gross gamma exposure rates ranged from 13 to $19 \mu \mathrm{R} / \mathrm{h}$ (Appendix Table B-1).

\section{Cost and Schedule}

Project costs and the schedule for remediation of Building 52 will be presented in a summary final report of GJPORAP interior area remediation activities.

\section{Occupational Exposure}

The results of personnel and area monitoring of exposure to workers and the public to radiological and nonradiological hazards from GJPORAP-related activities indicated no abovebackground exposures to radioparticulates, including radon daughters, ionizing radiation, or other hazards.

\section{Waste Volumes}

The remediation of Building 52 generated a total of 75 tons (68 metric tons), or approximately $47 \mathrm{yd}^{3}\left(36 \mathrm{~m}^{3}\right)$ of contaminated material, including building debris and soil. This material was disposed at the Cheney Disposal Cell.

\section{Final Condition}

All decontamination requirements identified in the ROD for GJPORAP have been satisfied for the soil at the former location of Building 52 (Table 3). The IVC will issue a Statement of Verification to signify concurrence that this portion of the remedial action achieved program objectives.

Radiologically contaminated material has been removed, and all remediated areas comply with the applicable provisions of 40 CFR 192 , DOE Order 5400.5, and FUSRAP/SFMP guidelines. Suspected occurrences of nonradiological contamination were investigated; no nonradiological contamination was identified.

Remediated areas have been restored to comply with floodplain permits, the Endangered Species Act, and other applicable regulations. Groundwater sampling will provide further assurance that contaminated materials currently managed on site will not pose any threat to human health or the environment. Sufficient data have been collected to document final site conditions and to demonstrate that cleanup levels specified in the ROD were attained. These data and associated information are available to the public and will be archived in the Certification Docket.

Because of the limitations of current technology and procedures for identifying and remediating radiologically contaminated materials, unknown deposits of contamination may be found in the future. The potential for encountering contamination during future construction activities will be determined and atrisk activities will be monitored for radiological and nonradiological contamination. The DOE-GJPO facility is routinely surveyed for radiation and other hazards.

No assessed hazardous substances were left in the remediated area; therefore, the area can be released for unrestricted use and unlimited exposure. At the time of this report, contamination is still present in other interior areas of the DOE-GJPO facility; access to these areas is controlled and will be addressed by future GJPORAP remedial actions. Once all the interior areas are remediated, the facility will be managed as a LTSM site by DOE until restoration of the alluvial aquifer by natural flushing occurs.

\section{Lessons Learned}

Lessons learned during remediation of Building 52 have been incorporated into subsequent operations. These lessons will be presented in a summary final report of the GJPORAP interior area remediation activities. 
Table 3. Building 52 Certification Summary

\begin{tabular}{|c|c|c|c|}
\hline $\begin{array}{l}\text { Certification } \\
\text { Criteria }\end{array}$ & Authorized Limit & $\begin{array}{l}\text { Number of } \\
\text { Observations }\end{array}$ & Results \\
\hline $\begin{array}{l}\text { Gamma Exposure } \\
\text { Rate (habitable } \\
\text { areas only) }\end{array}$ & $<20 \mu \mathrm{R} / \mathrm{h}$ above background. & None & $\begin{array}{l}\text { Not applicable (no habitable } \\
\text { areas). }\end{array}$ \\
\hline $\begin{array}{l}\text { Radon Decay- } \\
\text { Product Concen- } \\
\text { tration (habitable } \\
\text { areas only) }\end{array}$ & $\begin{array}{l}\text { Annual average shall not exceed } \\
0.02 \text { WL to the extent practicable, } \\
\text { and in no case shall exceed } \\
0.03 \text { WL. }\end{array}$ & None & $\begin{array}{l}\text { Not applicable (no habitable } \\
\text { areas). }\end{array}$ \\
\hline Scans & Elevated activity will be investigated. & $\begin{array}{l}\text { Gamma: } \\
\text { scanned } 100 \% \\
\text { of surface. } \\
\text { Alpha and } \\
\text { beta-gamma: } \\
\text { none }\end{array}$ & $\begin{array}{l}\text { Gamma: exposure rate range } \\
\text { was } 13 \text { to } 19 \mu \mathrm{R} / \mathrm{h}^{\mathrm{b}} \\
\text { Alpha and beta-gamma: not } \\
\text { applicable (no structural } \\
\text { surfaces). }\end{array}$ \\
\hline $\begin{array}{l}\text { Surface Activity } \\
\text { (structural surfaces } \\
\text { only) }\end{array}$ & $\begin{array}{l}\text { Alpha or beta-gamma activity shall } \\
\text { not exceed } 5,000 \mathrm{dpm} / 100 \mathrm{~cm}^{2} \text { fixed, } \\
1,000 \mathrm{dpm} / 100 \mathrm{~cm}^{2} \text { removable, } \\
\text { averaged over } 1 \mathrm{~m}^{2} \text {. }\end{array}$ & None & $\begin{array}{l}\text { Not applicable (no structural } \\
\text { surfaces). }\end{array}$ \\
\hline \multirow[t]{2}{*}{$\begin{array}{l}\text { Radionuclide } \\
\text { Concentrations } \\
\text { (soil surfaces only) }\end{array}$} & $\begin{array}{l}\text { Ra-226 and Th-230: } \\
\text { Shall not exceed } 5 \mathrm{pCi} / \mathrm{g} \text { above } \\
\text { background in the } 15-\mathrm{cm} \text { surface } \\
\text { layer, averaged over } 100 \mathrm{~m}^{2} \text {. } \\
\text { Shall not exceed } 15 \mathrm{pCi} / \mathrm{g} \text { above } \\
\text { background in any } 15-\mathrm{cm} \text {-thick soil } \\
\text { layer more than } 15 \mathrm{~cm} \text { below the } \\
\text { surface, averaged over } 100 \mathrm{~m}^{2} \text {. }\end{array}$ & $\begin{array}{l}\text { None } \\
1 \text { composite } \\
\text { sample } \\
\text { comprising } \\
6 \text { aliquots. }\end{array}$ & $\begin{array}{l}\text { Not applicable (soil surface } \\
>15 \mathrm{~cm} \text { deep). } \\
\text { Ra-226: } 6.2 \mathrm{pCi} / \mathrm{g}^{\mathrm{b}} \\
\text { Th-230:9.9 pCi/g (estimated) }{ }^{\mathrm{b}, \mathrm{c}}\end{array}$ \\
\hline & $\begin{array}{l}\text { Total uranium: } \\
\text { Shall not exceed } 106 \mathrm{pCi} / \mathrm{g} \text { above } \\
\text { background in any } 15-\mathrm{cm} \text { layer, } \\
\text { averaged over } 100 \mathrm{~m}^{2} \text {. }\end{array}$ & $\begin{array}{l}\text { Samples } \\
\text { scanned for } \\
\text { beta-gamma } \\
\text { activity. }\end{array}$ & $\begin{array}{l}\text { Not tested (surface activity } \\
<2,500 \mathrm{dpm} / 100 \mathrm{~cm}^{2} \text { ). }\end{array}$ \\
\hline Hot-Spot Criteria & Limit $=($ guideline value $)(100 / \text { area })^{0.5}$ & As required. & $\begin{array}{l}\text { Maximum concentrations below } \\
\text { hot-spot limit. }\end{array}$ \\
\hline
\end{tabular}

a Background activities are summarized in Table 2.

${ }^{b}$ Gamma exposure rates and radionuclide concentrations include background.

'Gamma scans did not exceed background by more than 30 percent. While gamma activity is a direct indicator of Ra-226 only, a relationship between Ra-226 and Th-230 has been established for the DOE-GJPO facility. Using regression analysis of the analytical results of 315 pairs of assessment and verification soil samples, this relationship was found to be Th-230 $=(1.42 \times \mathrm{Ra}-226)+1.13$ (DOE 1994). The mean Th-230 concentration of the soil beneath Building 52 is predicted with 95 percent confidence to be $9.9 \mathrm{pCi} / \mathrm{g}$.

Note: Th-232 is not a contaminant of concern in soils at the DOE-GJPO facility (DOE 1994).

Key:

$\begin{array}{lll}\mathrm{cm} & = & \begin{array}{l}\text { centimeter(s) } \\ \mathrm{dpm} / 100 \mathrm{~cm}^{2}\end{array} \\ \mathrm{~m}^{2} & = & \text { disintegration(s) per minute per } 100 \text { square centimeters } \\ \mathrm{pCi} / \mathrm{g} & = & \text { picoure meter(s) } \\ \mathrm{Ra}-226 & = & \text { radium-226 } \\ \mathrm{Th}-230 & = & \text { thorium-230 } \\ \mu \mathrm{R} / \mathrm{h} & = & \text { microroentgens per hour } \\ \mathrm{WL} & = & \text { working level }\end{array}$




\section{References}

10 CFR 835. U.S. Department of Energy, "Occupational Radiation Protection," U.S. Code of Federal Regulations.

40 CFR 192. U.S. Environmental Protection Agency, "Health and Environmental Protection Standards for Uranium and Thorium Mill Tailings," U.S. Code of Federal Regulations.

American Society of Mechanical Engineers (ASME), 1989. Quality Assurance Program for Nuclear Facilities, NQA-1, New York.

Rust Geotech. Field Assessments Procedures Manual, U.S. Department of Energy Grand Junction Projects Office, Grand Junction, Colorado.

\section{Health and Safety Manual}

(Manual 103), Volume 1, U.S. Department of Energy Grand Junction Projects Office, Grand Junction, Colorado.

\section{Quality Assurance Manual}

(Manual 101), U.S. Department of Energy Grand Junction Projects Office, Grand Junction, Colorado.

, 1993. "Comprehensive Building

Survey Completion Report of Building 52", memorandum from K.D. Briar, U.S. Department of Energy Grand Junction Projects Office, Grand Junction, Colorado, July 6.

, 1994a. "GJPORAP 1994 Building

D\&D Summary," internal planning document prepared by S.G. Corle, for U.S. Department of Energy Grand Junction Projects Office, Grand Junction, Colorado, July 26.

1994b. "Site Maintenance Daily

Logs," completed by R. H. Gregg, for U. S. Department of Energy Grand Junction Projects Office, Grand Junction, Colorado, September 22, $23,26,27$, and 28 .
1996. Personal communication

between J.E. Krabacher and C.L. Bruner of Rust Geotech, U.S. Department of Energy Grand Junction Projects Office, Grand Junction, Colorado, June 10.

U.S. Department of Energy (DOE), 1986. Radiologic Characterization of the Department of Energy Grand Junction Projects Office Facility, GJ-41, prepared by Bendix Field Engineering Corporation for the U.S.

Department of Energy Grand Junction Projects Office, Grand Junction, Colorado, January. 1987a. Historical Survey of the Grand Junction Projects Office FacilityHazardous (Non-Radioactive) Wastes, prepared by UNC Technical Services, Inc., for the U.S. Department of Energy Grand Junction Projects Office, Grand Junction, Colorado, February. , 1987b. Guidelines for Residual

Radioactive Material at Formerly Utilized Sites Remedial Action Program and Remote Surplus Facilities Management Program Sites, Rev. 2, March.

,1989a. Final Remedial

Investigation/Feasibility Study-Environmental Assessment for the U.S. Department of Energy

Grand Junction (Colorado) Projects Office Facility, DOE/EA-0402, prepared by UNC Geotech, Inc., for the U.S. Department of Energy Grand Junction Projects Office, Grand Junction, Colorado, July.

,1989b. "Review of Remedial Investigation/Feasibility Study (RI/FS) for a Site Which Is Not Included on the National Priorities List (NPL)," letter from Dee Williamson, U.S. Department of Energy Grand Junction Projects Office, to David Schaller, U.S. Environmental Protection Agency Region VIII, Grand Junction, Colorado, August 4. 
1990a. Grand Junction Projects

Office Remedial Action Project, Declaration for the Record of Decision and Record of Decision Summary [includes the Responsiveness Summary], prepared by UNC Geotech, Inc., for the U.S. Department of Energy Grand Junction Projects Office, Grand Junction, Colorado, April. 1990b. Grand Junction Projects Office Remedial Action Program, Radiological Assessment for Construction Phase 1B, prepared by UNC Geotech, Inc., for the U.S. Department of Energy Grand Junction Projects Office, Grand Junction, Colorado, April.

1990c. Grand Junction Projects

Office Remedial Action Project Remedial Action Plan, P-GJPO-142, prepared by UNC Geotech, Inc., for the U.S. Department of Energy Grand Junction Projects Office, Grand Junction, Colorado, December.

1994. Grand Junction Projects

Office Remedial Action Project, Justification for Certifying 47 Large-Area Verification Areas at the Grand Junction Projects Office, GJ-GJPO-94-1, prepared by Rust Geotech for the U.S. Department of Energy Grand Junction Projects Office, Grand Junction, Colorado, November.
1995. Survey Plan for Releasing

the Buildings at the Grand Junction Projects

Office for Unrestricted Use, P-GJPO-150, prepared by Rust Geotech for the U.S.

Department of Energy Grand Junction Projects Office, Grand Junction, Colorado.

DOE Order 5400.5, Radiation Protection of the Public and the Environment, Change 1.

DOE Order 5480.1B, Environment, Safety, and Health Program for Department of Energy Operations, Change 5.

DOE Order 5480.4, Environmental Protection, Safety, and Health Protection Standards.

DOE Order 5480.11, Radiation Protection for Occupational Workers, Change 2. 
Appendix A

Applicable Program and Quality Assurance Requirements and Procedures 
This page intentionally blank 


\section{GJPORAP Program Management}

Operations Management Policy Manual

(Manual 104)

Project Control System Manual (Manual 107)

Management Policies Manual (Manual 100), Section 1, "General Administration," and Section 12, "Organization Functions and Responsibilities"

Remedial Action Statements of Work

Grand Junction Projects Office Desk Procedures Manual

Grand Junction Projects Office Remedial Action Project (GJPORAP), Grand Junction, Colorado, Community Relations Plan Update

Grand Junction Projects Office Remedial Action Project Quality Assurance Program Plan,

P-GJPO-141

Grand Junction Projects Office Remedial Action Project Records Management Plan, P-GJPO-143

Productivity/Quality Improvement Manual

(Manual 109)

\section{GJPORAP Construction Management}

Operations Management Policy Manual

(Manual 104)

Operations Department Construction

Procedures Manual

\section{Engineering}

Engineering Support Procedures Manual

AutoCAD Standards Manual

\section{Assessment/Verification}

Land Survey Support Procedures

AutoCAD Standards Manual

Environmental Procedures Catalog

(Manual 116)

\section{Laboratory Services}

\section{Analytical Laboratory}

Analytical Chemistry Laboratory Administrative Plan and Quality Control Procedures

Analytical Chemistry Laboratory Handbook of Analytical and Sample Preparation Procedures, Volumes I, II, and III

Gamma-Ray Spectroscopy System Operations Methods Manual

Environmental Instrumentation Laboratory

Calibration Control Program for Measurement and Test Equipment and Measurement Standards

Electronics Laboratory Procedures

\section{Quality Assurance}

Quality Assurance Desk Instructions and Administrative Procedures Manual (Manual 301)

\section{Health, Safety, and Security}

Health and Safety Manual, Volume 2

(Manual 103)

Health and Safety Desktop Procedures

(Manual 303)

Grand Junction Projects Office Remedial Action Project Health and Safety Plan, P-GJPO-144 


\section{Contracts and Procurement}

Management Policies Manual (Manual 100), Section 5, "Procurement"

Procurement Manual

Stores, Property, and Transportation (SPAT)

Manual (Manual 114)

Rust Guide for Preparing a Purchase Requisition

\section{Information Services}

\section{Computer Support}

Information Services Manual (Manual 105)

Publications and Records

Management Policies Manual (Manual 100), Section 2, "Documentation Systems," and Seçtion 13, "Records Management"

\section{Human Resources}

Training and Employee Development

Management Policies Manual (Manual 100), Section 3, "Human Resources"

\section{Other Guidance}

40 CFR 261, "Identification and Listing of Hazardous Waste."

40 CFR 300, "National Oil and Hazardous Substances Pollution Contingency Plan."

A Manual for Implementing Residual Radioactive Material Guidelines Using RESRAD Version 4.0, Argonne National Laboratory, June 1989.

"Approval of the Grand Junction Projects Office Remedial Action Project: National Environmental Policy Act and Comprehensive Environmental Response, Compensation, and Liability Act Documents" DOE, February 29, 1990.
"Calculation of Total Uranium Specific Activity From Total Uranium Chemical Concentration by Weight," Rust Geotech, November 11, 1994.

Community Relations in Superfund: A

Handbook, EPA, January 1992.

Defense Decontamination and Decommissioning Program: Program Management Plan, DOE, December 1989.

DOE Order 4700.5, Project Control System Guidelines.

DOE Order 5400.4, Comprehensive Environmental Response, Compensation, and Liability Act Requirements.

DOE Order 5700.6C, Quality Assurance.

DOE Order 5820.2A, Radioactive Waste Management.

Exemption No. DOT-E 10594, Research and Special Programs Administration, U.S.

Department of Transportation, May 28, 1992.

Environmental Implementation Guide for Radiological Survey Procedures, draft report, DOE, November 1992.

GJPORAP/IVC Project Management Summary, ORNL, May 1994.

Grand Junction Projects Office Remedial Action Project (GJPORAP), Grand Junction, Colorado, Community Relations Plan Update, DOE, July 1990.

Grand Junction Projects Office Remedial Action Project, Health and Safety Plan, DOE, February 1994.

Grand Junction Projects Office Remedial Action Project Quality Assurance Program Plan, Rev. 5, DOE, September 1990.

Grand Junction Projects Office Remedial Action Project, Radiological Sampling and Verification Plan, Phase IVA, DOE, November 1993. 
Guidelines for Decontamination of Facilities and Equipment Prior to Release for Unrestricted Use or Termination of Licenses for Byproduct, Source, or Special Nuclear Material, U.S. Nuclear Regulatory Commission, 1982.

Interim Final Guidance on Preparing Superfund Decision Documents: The Proposed Plan, The Record of Decision, Explanation of Significant Differences, The Record of Decision Amendment, EPA, July 1989.

Limits for Intakes of Radionuclides by Workers, International Commission on Radiological Protection (ICRP), August 1982.

Manual for Conducting Radiological Surveys in Support of License Termination, Oak Ridge Associated Universities, June 1992.

Procedures for Completion and Deletion of National Priority List Sites, U.S. Environmental Protection Agency (EPA), October 1988.

Project Plan for the U.S. Department of Energy Grand Junction Projects Office Remedial Action Project, DOE, March 1986.

Proposed GJPORAP Release Criteria and Scope Impacts," DOE, July 20, 1989.
Public Participation in Environmental Restoration Activities, DOE, November 1991.

Radiometric Survey of the Grand Junction Facility, U.S. Department of Energy (DOE), May 1982.

Recommendations of the ICRP, ICRP, August 1987.

Record of Decision for Remedial Action at the Climax Uranium Company Uranium Mill Site, Grand Junction, Colorado, DOE, August 1988.

SFMP Resource Manual, DOE, 1989.

Verification and Certification Protocol for the Office of Environmental Restoration, Formerly Utilized Sites Remedial Action Program and Decontamination and Decommissioning Program, Rev. 3, DOE, November 1990.

Work Plan for Independent Verification of the Grand Junction Projects Office Remedial Action Project, Oak Ridge National Laboratory (ORNL), October 1991. 
This page intentionally blank 


\section{Appendix B}

Final Radiological Conditions 
This page intentionally blank 
Table B-1 summarizes the post-excavation sampling and measurement results for the verification area encompassing the site of Building 52. The sample was acquired prior to backfilling. The sample is a composite comprising individual aliquots representing the 6-inch-deep soil layer at the bottom of the excavation. The sample was analyzed for radium-226 (Ra-226) using the Opposed Crystal System (OCS). The concentration of Ra-226 is expressed in picocuries per gram ( $\mathrm{pCi} / \mathrm{g}$ ), and includes background. The post-excavation gamma exposure rate range is expressed in microroentgens per hour $(\mu R / h)$. The remediated area is shown on Figure 2.

Table B-1. Post-Remediation Sample/Measurement Results for an Exterior Area

\begin{tabular}{ccccc}
\hline $\begin{array}{c}\text { Verification } \\
\text { Area }\end{array}$ & $\begin{array}{c}\text { Gamma } \\
\text { Exposure Rate }(\mu \mathrm{R} / \mathrm{h})\end{array}$ & $\begin{array}{c}\text { Soil Sample } \\
\text { Ticket No. }\end{array}$ & $\begin{array}{c}\text { Concentration } \\
(\mathrm{pCi} / \mathrm{g})\end{array}$ & $\begin{array}{c}\text { Ra-226 } \\
\text { Average Depth } \\
\text { of Excavation } \\
\text { (inches) }\end{array}$ \\
\hline V-B52-1 & $13-19$ & NCH 838 & 6.2 & 30 \\
\hline
\end{tabular}


This page intentionally blank 